\title{
Pure-transvaginal natural orifice transluminal endoscopic surgery (NOTES) ovariohysterectomy in bitches: a preliminary feasibility study
}

\author{
Ovário-histerectomia transvaginal pura por abordagem endoscópica transluminal por orifícios naturais \\ (NOTES) em cadelas: estudo preliminar de factibilidade da técnica
}

\author{
Marco Augusto Machado Silva ${ }^{\mathrm{I}}$ Gilson Hélio Toniollo ${ }^{\mathrm{II}}$ Karym Christine de Freitas Cardoso ${ }^{\mathrm{III}}$ \\ Carolina Quarterone ${ }^{\mathrm{I}}$ Maurício Veloso Brun ${ }^{\mathrm{IV}}$
}

\begin{abstract}
Natural orifice transluminal endoscopic surgery (NOTES) is a relatively new surgical access for minimally invasive surgery, which is being widely studied in human medicine. However, few studies focusing on its applicability in the small animal practice have been performed so far. The aim of the current study was to evaluate the feasibility of pureNOTES transvaginal ovariohysterectomy in bitches. Five bitches were evaluated. The abdomen was accessed through an $11 \mathrm{~mm}$ trocar inserted through a vaginal incision. Using a rigid endoscope with working channel, the ovarian pedicles were coagulated and sectioned using bipolar diathermy. The uterine horn was pulled into the trocar and exteriorized along with the cannula. The uterine body and vessels were coagulated or ligated. The uterine stump was replaced into the abdominal cavity and the pneumoperitoneum drained. Pure-NOTES OHE was successfully accomplished in four out of five bitches. In the first try, it was converted to a hybrid-NOTES technique due to instrument failure. Mean surgical time was 52.1 ( $S D \pm 11.5$ minutes) for the pure-NOTES technique. Pure-NOTES OHE is feasible in bitches, which may result in no major complications and excellent surgical recovery.
\end{abstract}

Key words: canine, spay, surgical technique, transvaginal NOTES.

RESUMO

Cirurgia endoscópica por orifícios naturais (NOTES) constitui um acesso cirúrgico relativamente novo para abordagem minimamente invasiva, a qual vem sendo amplamente estudada na medicina humana. Porém, poucos estudos envolvendo sua aplicação na prática cirúrgica de pequenos animais foram realizados até o momento. O objetivo do presente estudo foi avaliar a factibilidade da ováriohisterectomia transvaginal por NOTES pura em cadelas. Cinco cadelas foram avaliadas. A cavidade abdominal foi acessada por um trocarte de $11 \mathrm{~mm}$ introduzido por uma incisão vaginal. Empregando-se um endoscópio rígido com canal de trabalho, os pedículos ovarianos foram coagulados e seccionados usando-se diatermia bipolar. O corno uterino foi tracionado para o interior do trocarte e exteriorizado juntamente com a cânula. O corpo e vasos uterinos foram coagulados ou ligados com sutura. O coto uterino foi reposicionado na cavidade abdominal e o pneumoperitônio, drenado. O procedimento foi realizado com sucesso em quatro das cinco cadelas. $\mathrm{Na}$ primeira tentativa, houve conversão para uma técnica de NOTES-híbrida, devido à quebra de uma pinça de coagulação. O tempo cirúrgico médio foi 52,1 ( $D P \pm 11,5$ minutos) para a técnica de NOTES pura. A OHE por NOTES pura é factível em cadelas, sem resultar em complicações maiores e proporcionando excelente recuperação pós-operatória.

Palavras-chave: caninos, castração, técnica cirúrgica, NOTES transvaginal.

\section{INTRODUCTION}

Ovariohysterectomy (OHE) is one of the most routinely performed surgeries in the veterinary practice. Furthermore, several surgical techniques of $\mathrm{OHE}$ and their benefits and complications have been

'Departamento de Clínica e Cirurgia, Faculdade de Ciências Agrárias e Veterinárias (FCAV), Universidade Estadual Paulista "Júlio de Mesquita Filho" (UNESP), Jaboticabal, SP, Brasil.

IIDepartamento de Medicina Veterinária Preventiva e Reprodução Animal, FCAV, UNESP, Jaboticabal, SP, Brasil.

"IIFaculdade de Medicina Veterinária, Universidade de Franca (UNIFRAN), Franca, SP, Brasil.

${ }^{\text {Iv }}$ Centro de Ciências Rurais (CCR), Universidade Federal de Santa Maria (UFSM), Avenida Roraima, 1000, Cidade Universitária, Camobi, 97105-900, Santa Maria, RS, Brasil. E-mail: mbrun@upf.br.*Autor para correspondência. 
widely discussed for decades (PEARSON, 1973; SPAIN et al., 2004). The conventional OSH usually is accessed through median incision, which frequently encompasses the half or the middle third of the umbilicopubic distance. Pain is one of the most common early postoperative complications of laparotomy and frequently requires rescue analgesia (DEVITT et al., 2005). In the past 10 years, several laparoscopic and video-assisted spay techniques were developed in small animals (AUSTIN et al., 2003; DEVITT et al., 2005; FREEMAN et al., 2009).

Natural orifice transluminal endoscopic surgery (NOTES) is a relatively new concept on surgical access, mainly for abdominal surgery. The main natural orifices used in NOTES include the oral cavity (transgastric approach), vagina and colon (KAVIC, 2006). Although accessing the abdomen through natural organic orifices may be challenging, several advantages of NOTES were highlighted in human medicine and animal models. Absence of cutaneous scars, short hospital stay, short convalescence period and less postoperative pain are the main benefits of NOTES (PEARL \& PONSKY, 2008).

A technique of hybrid-NOTES OHE in dogs has been described, which led to fast recovery and minimal surgical trauma (BRUN et al., 2009; BRUN et al., 2011). However, to our knowledge, the technique of pureNOTES OHE has not been published to date. Therefore, the aim of the present study was to evaluate the feasibility of pure-NOTES ovariohysterectomy in bitches.

\section{MATERIAL AND METHODS}

Five young bitches, weighting $12.6 \mathrm{~kg}$ ( $\mathrm{SD} \pm 2.7$ ), were admitted for elective ovariohysterectomy. Physical exam was performed and blood samples were collected for routine preoperative examination. The bitches were fasted for 12 hours and their abdomen and perineum were clipped. The patients were premedicated with acepromazine $\left(0.02 \mathrm{mg} \mathrm{kg}^{-1}\right)$, midazolam $\left(0.4 \mathrm{mg} \mathrm{kg}^{-1}\right)$ and morphine $\left(0.5 \mathrm{mg} \mathrm{kg}^{-1}\right)$, intramuscularly. Anesthesia was induced with propofol $\left(6 \mathrm{mg} \mathrm{kg}^{-1} \mathrm{IV}\right)$ and maintained with isoflurane in $100 \%$ oxygen. Additionally, epidural block was performed with lidocaine $\left(0.13 \mathrm{ml} \mathrm{kg}^{-1}\right)$ and bupivacaine $\left(0.13 \mathrm{ml} \mathrm{kg}^{-1}\right)$. The animals were positioned in dorsal recumbency. The abdomen was prepared aseptically and the vagina was rinsed with $0.1 \%$ PVP-I solution in normal saline $\left(10 \mathrm{ml} \mathrm{kg}^{-1}\right)$.

For the transvaginal access to the abdominal cavity, the mucosa of the vaginal fornix was grasped with two Kelly curved forceps and pulled caudally. A stab incision was performed in the mucosa (Figure 1A) and the submucosal layer was dissected with curve Metzenbaum scissors. A 11mm disposable trocar with blunt tip was blindly inserted into the abdominal cavity through the vaginal mucosa incision (Figure 1B). Complete insertion of the trocar was certified by abdominal palpation. $\mathrm{CO}_{2}$ insufflation was performed until intra-abdominal pressure of $10 \mathrm{mmHg}$ was achieved (1lmin'-1 gas flow).

A $10.5 \mathrm{~mm}$ operative laparoscope ${ }^{\mathrm{a}}$ with a $5.5 \mathrm{~mm}$ working channel was inserted into the abdominal cavity for initial inspection. The animal was turned to the left in order to expose the right ovarian pedicle. A $42 \mathrm{~cm}$ laparoscopic Babcock forceps was inserted through the working channel of the laparoscope and the right ovary was grasped and raised to the abdominal wall for trans-abdominal suspension suture (Figure 1C). A 42cm laparoscopic bipolar forceps $\mathrm{s}^{\mathrm{b}}$ was used to coagulate and cut the ovarian pedicle simultaneously (Figure 1D). The bipolar coagulation was set to 40 watts in the electrosurgical generator ${ }^{c}$.

The animals were turned to the right. The same surgical approach was performed on the opposite ovarian pedicle. The left ovary was then grasped with the Babcock forceps, the tacking suture was released and the ovary was pulled into the trocar (Figure 1E). The trocar was then withdrawn from the vaginal canal along with the left ovary. Gentile traction was performed to exteriorize the left uterine horn, the uterine body and the right uterine horn and ovary. The uterus was ligated with double circulating/transfixing ligature with polyglactin 910 2-0 thread and resected in bitch no 1 and 2, and coagulated and cut with the bipolar forceps (Figure 1F) in bitches no 3, 4 and 5. The uterine stump was checked for bleeding and repositioned within the abdominal cavity using gentle digital pressure. Careful inspection of the vaginal incision was carried out for bleeding. No suture was applied at the vaginal incision and the bitches were ready to convalesce.

The procedure could be converted to hybrid-NOTES with insertion of an $11 \mathrm{~mm}$ trocar at the midline, $2 \mathrm{~cm}$ caudally from the umbilicus, if needed. In case of massive/uncontrollable bleeding, laparotomy would be carried out to manage the hemorrhage adequately. Cephalexin (30 $\mathrm{m} \mathrm{kg}^{-1}$ VO BID for 6 days), tramadol (2 $\mathrm{mg} \mathrm{kg}^{-1} \mathrm{VO}$ BID for 3 days) and meloxicam $\left(0.1 \mathrm{mg} \mathrm{kg}^{-1}\right.$ VO SID for 3 days) were given postoperatively.

The surgical procedure was divided into seven stages: transvaginal access, establishment of the pneumoperitoneum, approach to the right/left ovarian pedicle, exteriorization of the uterus, hemostasis of the uterine stump and vessels and inactive/inoperative time. The time of each surgical stage was analyzed descriptively and expressed as mean value $( \pm S D)$, in minutes (min). 


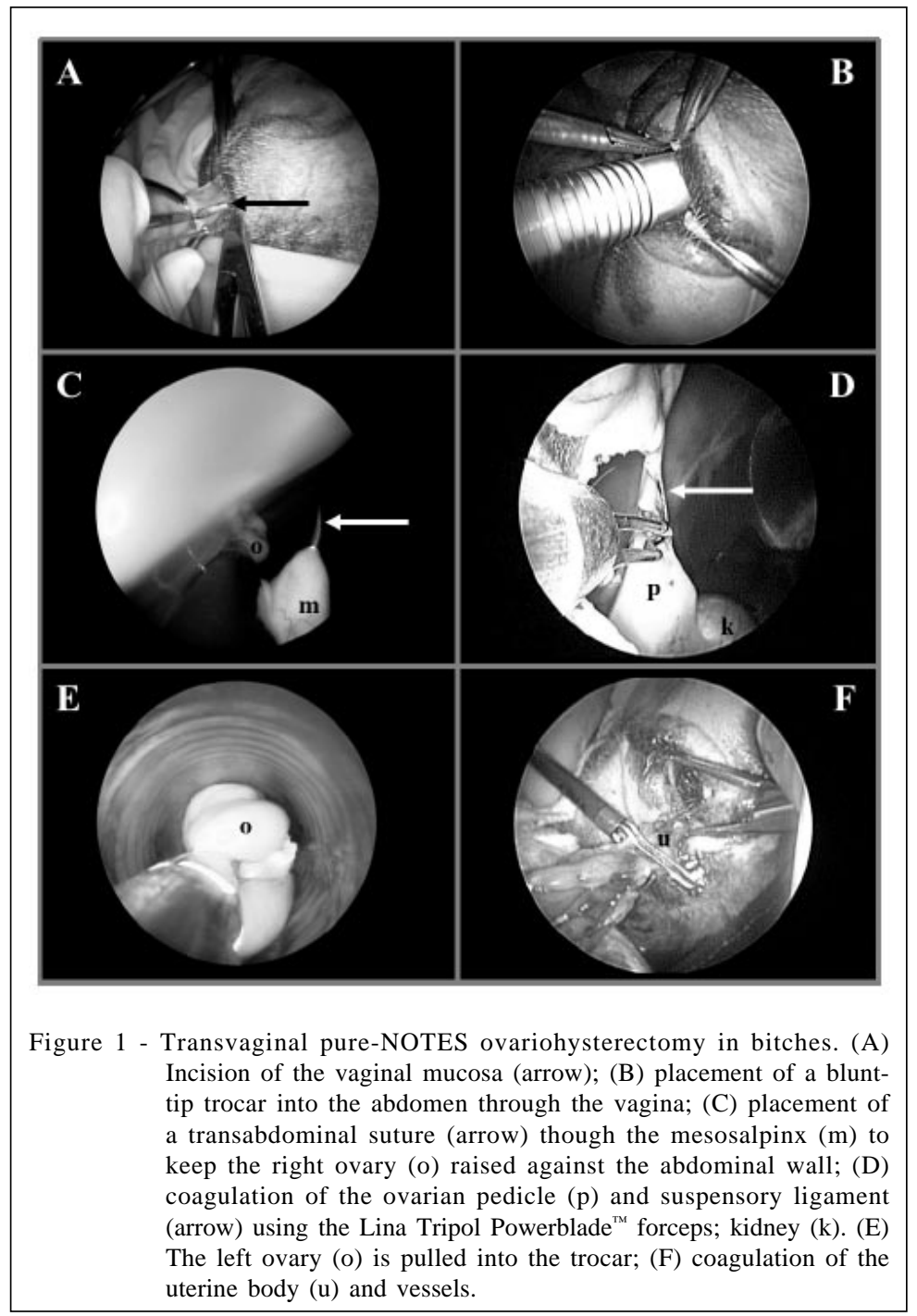

At the end of the surgical procedure, the ovaries and uterus were fixated in $10 \%$ buffered formalin for histological evaluation. After standard histological preparation, the slides were stained with hematoxiline and eosin (H\&E) technique. The slides were evaluated under optical microscopy. The histological findings were analyzed descriptively.

\section{RESULTS}

The mean overall surgical time was 52.1 ( $\mathrm{SD} \pm 11.5$ minutes). Approximately 8 minutes ( $\mathrm{SD} \pm 1.9$ minutes) were spent in order to reach the abdominal cavity through the vagina. The blind insertion of the trocar was safe and easy to perform.

The first attempt of pure-NOTES OHE (animal $n^{\circ} 1$ ) was not successful due to instrument failure. The disposable bipolar coagulation/cut forceps was bent and broke inside the working channel of the endoscope during the coagulation of the left ovarian pedicle. The procedure was then converted to a hybridNOTES technique. The rigid endoscope was introduced through the abdominal port and a $10 \mathrm{~mm}$ clip applier was inserted through the transvaginal port. The left ovarian pedicle was triple-ligated with titanium clips and the pedicle was resected with $5 \mathrm{~mm}$ Metzenbaum scissors, inserted through the transvaginal port. The same technique was used to reach hemostasis of the right ovarian pedicle. The uterus was exteriorized transvaginally and doubleligated with 2-0 polyglactin 910 . In bitch $n^{0} 1$, hybridNOTES OHE was accomplished in 92.5 minutes. Animal no 1 was excluded from the assessment of the surgical time. The time spent on each surgical stage is shown in table 1 and the linear distribution of surgical time is expressed in figure 2 . 
No complications regarding transoperative bleeding, postoperative pain or infection were noted. Minor complications included mild vaginal bleeding, which stopped spontaneously within 24 hours in all bitches. According to the owner, bitch $\mathrm{n}^{\mathrm{0}} 5$ presented vaginal bleeding on the $21^{\text {th }}$ day post-op, which persisted for six hours and ceased without adjuvant treatment. The blood loss was not possible to be precisely estimated. Moreover, the cause of such finding could not be determined, once the owner did not take the animal to the Veterinary Hospital for examination. There was slight vaginal swelling in all bitches. Vaginal swelling was absent in all patients following four days of the surgical procedure. Hypothermia (core body temperature $<36^{\circ} \mathrm{C}$ ) occurred in all bitches, which resolved within the first hour post-op.

The histological assessment revealed that the ovaries were completely resected with margins in all bitches. Three out of five uterus presented normal histological pattern of anestrus phase. The uterus of bitch $\mathrm{n}^{\mathrm{0}} 1$ presented severe cystic endometrial hyperplasia $(\mathrm{CEH})$, which was histologically characterized by great number of large cysts in the endometrium. There was no local inflammatory response nor fibroblast proliferation. One of the bitches was spayed about 45 days postpartum. Histologically, there were large masses of collagen fibers detaching from the placental sites.

\section{DISCUSSION}

The pure-transvaginal NOTES OHE technique was feasible in small or medium-size bitches. The surgical procedures presented similar operative time to those of other laparoscopic techniques for OHE. A three-portal laparoscopic ovariohysterectomy with harmonic scalpel in bitches was described. The mean surgical time was 55.7 minutes (HANCOCK et al., 2005). In a surgical trial involving transgastric NOTES, laparoscopic approach and open oophorectomy, the mean surgical time was 76, 44 and 35 minutes, respectively (FREEMAN et al., 2011). The shortest mean surgical time for endoscopic OHE described in the currently available literature was 20.8 (SD \pm 4.0$)$ minutes (DEVITT et al., 2005). A two-port videoassisted technique was used and the hemostasis of the ovarian pedicles was carried out with a simultaneous bipolar coagulation/cut forceps (DEVITT et al., 2005). It is believed that the surgical time obtained using the pure-NOTES OHE technique purposed in the current study was fairly good. However, it is truly believed that optimal surgical time will be achieved as soon as the learning curve has been reached.

The development of the pure-NOTES OHE was based on the principles of the sigle-port videoassisted OHE technique (SILVA et al., 2011), associated with the principles of hybrid-NOTES OHE (BRUN et al., 2009; BRUN et al., 2011). Based in the results of a previous assessment of the learning curve of singleport video-assisted OHE in bitches (SILVA et al., 2011), it was hypothesized that between 20 and 30 pureNOTES OHE should be performed in order to reach optimal surgical time.

The use of a standard operative laparoscope for the NOTES OHE in bitches turned this technique into an attractive option for surgical contraception. However, the endoscope reached only the caudal part of the abdomen, at the umbilical level. It is believed that the use of recently development NOTES flexible endoscope and instruments would substantially increase the cost-effectiveness, technical difficulties and the surgical time in the vaginal access for NOTES, as mentioned in other study (FREEMAN et al., 2009).

Table 1 - Intra-operative time (min) of each stage of the transvaginal pure-NOTES ovariohysterectomy in bitches.

\begin{tabular}{|c|c|c|c|c|c|c|c|}
\hline \multirow{2}{*}{ Surgical stages } & \multicolumn{5}{|c|}{ 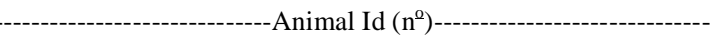 } & \multirow{2}{*}{ Mean } & \multirow{2}{*}{ SD } \\
\hline & $1^{\S}$ & 2 & 3 & 4 & 5 & & \\
\hline Transvaginal access & 9.7 & 9.2 & 8.3 & 9.5 & 5.4 & 8.1 & 1.9 \\
\hline Pneumoperitoneum & 2.7 & 2.0 & 1.5 & 3.0 & 0.7 & 1.8 & 1.0 \\
\hline Approach to the right ovarian pedicle & - & 14.5 & 8.7 & 8.0 & 11.6 & 10.7 & 3.0 \\
\hline Approach to the left ovarian pedicle & - & 12.5 & 7.2 & 10.0 & 15.5 & 11.3 & 3.5 \\
\hline Exteriorization of the uterus & - & 7.8 & 7.0 & 6.0 & 2.7 & 5.9 & 2.2 \\
\hline Hemostasis of the uterine body & - & 6.3 & 0.9 & 1.5 & 2.5 & 2.8 & 2.4 \\
\hline Inactive/inoperative time ${ }^{*}$ & - & 16.5 & 9.9 & 11.8 & 7.7 & 11.5 & 3.7 \\
\hline Overall surgical time & 92.5 & 68.8 & 43.5 & 49.8 & 46.1 & 52.1 & 11.5 \\
\hline
\end{tabular}

*Including time spent for cleaning the lens of the endoscope, repositioning the patient and inspecting the abdominal cavity and ovarian pedicles. ${ }^{\S}$ Animal $n^{\circ} 1$ was excluded from the assessment of the global surgical time. 


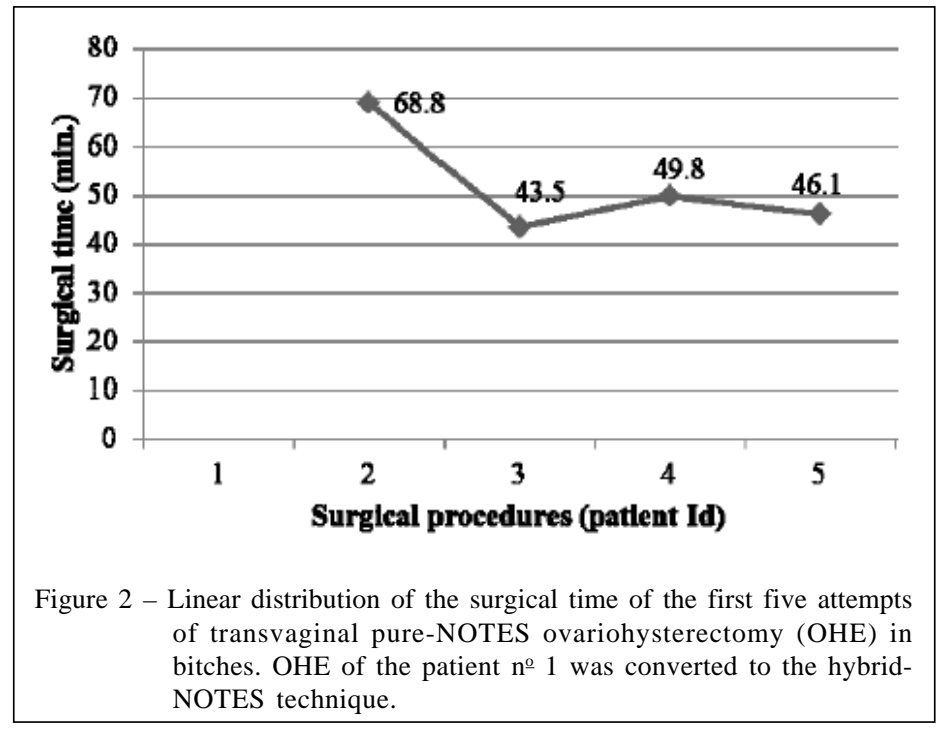

It is believed that the pure-NOTES technique could be one of the less invasive surgical approaches for OHE in bitches, which requires no wound care and may produce less painful stimuli during the surgery and on the early post-op period. Furthermore, the absence of abdominal incision can reduce to zero the possibility of postsurgical herniation or evisceration, as the only incision required is performed within the vagina. The pure-NOTES technique required no additional port and eliminated the possibility of abdominal herniation, emphysemas and seroma in the present study.

One of the disadvantages of the pureNOTES OHE is the lack of compatibility between the size of the instruments and the animals' biometry. The working length of the operative-laparoscope was $27 \mathrm{~cm}$ and the total reach of the $42 \mathrm{~cm}$ bipolar forceps inside the working channel of the endoscope was $32 \mathrm{~cm}$. Thus, it was observed that bitches presenting more than $30 \mathrm{~cm}$ in length between the ovarian pedicles and the vulva are not good candidates for the pure-NOTES technique. However, the technique should be tested in larger animals in order to verify such hypothesis.

Another limitation of the pure-NOTES technique is inherent to the amount of fat tissue surrounding the ovarian bursa. In such case, the exteriorization of the ovaries may be more difficult, increasing the risk of rupture of the uterine horn or loss of ovarian tissue within the abdominal cavity, as reported in other study (HANCOCK et al., 2005). However, the ovary and adjacent tissues entered the $11 \mathrm{~mm}$ vaginal port and vaginal exteriorization was possible in all animals of the current study.

It was hypothesized that the antibiotic therapy was effective in avoiding post-operative infection. The literature regarding the harmfulness of the canine vaginal microflora to the peritoneal cavity and the prophylaxis of post-surgical infection following NOTES procedures in dogs is sparse. Moreover, the vaginal defect was not sutured, which could communicate the vaginal canal to the abdominal cavity for hours or days. However, such fact has not been assessed so far. Therefore, the use of post-operative antibiotics for six days in the current trial was coherent.

The vaginal swelling has possibly lasted more days in bitch no 3 due to the smaller diameter of its vagina. It was observed that tight vaginal canal leaded to major trauma during insertion of the $11 \mathrm{~mm}$ trocar. Therefore, pure-NOTES OHE may not be applicable in bitches whose vagina does not fit an $11 \mathrm{~mm}$ or thicker trocar. In hybrid transvaginal NOTES OHE technique, the authors found that it was possible to insert a $11 \mathrm{~mm}$ trocar through the vagina in one bitch weighting 4.2kg (BRUN et al., 2009).

Vaginal bleeding in animal no 5 resulted in no major clinical relevance and was conservatively treated. It is truly believed that a simple modification of the technique presented in the current study would prevent early or late vaginal wound bleeding.

Histological findings of the bitch $n$ o 4 were within the normal patterns of normal uterine involution in the canine specie (AL-BASSAM, et al., 1981). The histological findings of the uterus of bitch $n^{0} 1$ were compatible with severe cystic endometrial hyperplasia (DE BOSSCHERE et al., 2001, which was successfully managed with the hybrid-NOTES OHE technique. The pure-NOTES OHE seems to be feasible in animals owning uterine disorders. Moreover, the present study confirmed the viability of conversion from the pure-NOTES to the hybrid-NOTES technique (BRUN et al., 2011) for 
managing transoperative complications of OHE instead of laparotomy, which has never been reported before. Such management leaded to minimal abdominal trauma as only one $11 \mathrm{~mm}$ extra port was required.

\section{CONCLUSION}

The authors concluded that pure-NOTES OHE is feasible in dogs. Pure-NOTES ovariohysterectomy needs to be studied in order to prove its security and minimal invasiveness, especially when long-term postoperative complications are concerned.

\section{BIOETHICS AND BIOSSECURITY COMMITTEE APPROVAL}

The current study was approved by the Committee for Ethics on the Use of Animals of the School of Agrarian and Veterinary Sciences of the São Paulo State University (CEUA protocol number 019211-08)

\section{AKNOWLEDGEMENTS}

The authors would like to thank Mrs. Vilma Peixeiro (Marketing and Sales Manager of WEM Electronic Equipment, Ribeirão Preto, SP, Brazil) and Mr. Niclas Woye (International Sales Manager of LINA Medical, Copenhagen area, Denmark) for providing the Lina Tripol Powerblade ${ }^{\mathrm{TM}}$ for the development of the current study.

\section{ACQUISITION SOURCES}

a - H.B. Strattner, Ribeirão Preto-SP.

b - Lina Tripol Powerblade ${ }^{\mathrm{TM}}$, WEM and Vivamed, Ribeirão Preto-SP.

c - HF-120 ${ }^{\mathrm{TM}}$, WEM and Vivamed, Ribeirão Preto-SP.

\section{REFERENCES}

AL-BASSAM, M.A. et al. Normal postpartum involution of the uterus in the dog. Canadian Journal of Compared Medicine, v.45, n.3, p.217-232, 1981. Available from: <http:/ /www.ncbi.nlm.nih.gov/pmc/articles/PMC1320212/pdf/ compmed00019-0009.pdf>. Accessed: Jun. 10, 2011.

AUSTIN, B. et al. Laparoscopic ovariohysterectomy in nine dogs. Journal of the American Animal Hospital Association, v.39, n.4, p.391-396, 2003. Available from: <http:/ /www.jaaha.org/cgi/reprint/39/4/391>. Accessed: Jan. 252011.

BRUN, M.V. et al. NOTES híbrida na realização de ovariosalpingohisterectomia em 12 cadelas. Brazilian Journal of Videoendoscopic Surgery, v.2 (suppl.), p.7071, 2009. Available from: <http://www.sobracil.org.br/revista/ jv020201s/bjvs020201_1.pdf>. Accessed: Mar. 15, 2011.

BRUN, M.V. et al. Ovariohysterectomy in a dog by hybrid NOTES techinique - a case report. Canadian Veterinary Journal, v.52, p.637-640, 2011. Available from: <http:// canadianveterinarians.net/publications-journal-issueprevious2.aspx>. Accessed: Mar. 15, 2011.
DE BOSSCHERE, H. et al. Cystic endometrial hyperplasiapyometra complex in the bitch: should the two entities be disconnected? Theriogenology, v.55, n.7, p.1509-1519, 2001. Available from: <http://www.sciencedirect.com/science/article/ pii/S0093691X01004988>. Accessed: Mar. 15, 2011. doi:10.1016/S0093-691X(01)00498-8.

DEVITT, C.M. et al. Duration, complications, stress, and pain of open ovariohysterectomy versus a simple method of laparoscopic-assisted ovariohysterectomy in dogs. Journal of the American Veterinary Medical Association, v.227, n.6, p.921-927, 2005. Available from: <http://www.avma.org/ avmacollections/spay_neuter/javma_227_6_921.pdf $>$. Accessed: Jan. 15, 2011.

FREEMAN, L.J. et al. Oophorectomy by natural orifice transluminal endoscopic surgery: feasibility study in dogs. Gastrointestinal Endoscopy, v.69, n.7, p.1321-1332, 2009. Available from: <http://www.sciencedirect.com/science/article/ pii/S0016510708028186>. Accessed: Mar. 15, 2011. doi:10.1016/j.gie.2008.10.02.

FREEMAN, L.J. et al. Comparison of pain and postoperative stress in dogs undergoing natural orifice transluminal endoscopic surgery, laparoscopic, and open oophorectomy. Gastrointestinal Endoscopy, v.72, n.2, p.373-380, 2010. Available from: <http://www.sciencedirect.com/science/article/ pii/S0016510710001392>. Accessed: Jun. 10, 2011. doi:10.1016/j.gie.2010.01.066.

HANCOCK, R.B. et al. Comparison of postoperative pain after ovariohysterectomy by harmonic scalpel-assisted laparoscopy compared with median celiotomy and ligation in dogs. Veterinary Surgery, v.34, p.273-282, 2005. Available from: <http://onlinelibrary.wiley.com/doi/10.1111/j.1532950x.2005.00041.x/pdf>. Accessed: Jun. 10, 2011. doi:10.1111/j.1532-950X.2005.00041.x.

KAVIC, M.S. Natural orifice translumenal endoscopic surgery: "NOTES". Journal of the Society of Laparoscopic Surgery, v.10, p.133-134, 2006. Available from: <http:// www.ncbi.nlm.nih.gov/pmc/articles/PMC3016136/pdf/jsls-102-133.pdf>. Accessed: Jan. 28, 2011.

PEARL, J.P.; PONSKY, J.L. Natural orifice translumenal endoscopic surgery: a critical review. Journal Gastrointestinal Surgery, v.12, p.1293-1300, 2008. Available from: <http://www.springerlink.com/content/ 50x3601453572q50/fulltext.pdf $>$. Accessed: Jun. 10, 2011. doi: 10.1007/s11605-007-0424-4.

PEARSON, H. The complications of ovariohysterectomy in the bitch. Journal of Small Animal Practice, v.14, n.5, p.257-266, 1973. Available from: <http:// onlinelibrary.wiley.com/doi/10.1111/j. 1748 5827.1973.tb06457.x/pdf $>$. Accessed: Jan. 2, 2011.

SILVA, M.A.M. et al. Single-port video-assisted ovariohysterectomy in bitches: retrospective study of 20 cases. Ciência Rural, v.41, n.2, p.294-300, 2011. Available from: <http://www.scielo.br/pdf/cr/v41n2/a871cr4012.pdf>. Accessed: Jun. 10, 2011 . doi:10.1590/S0103-84782011005000013.

SPAIN, C.V. et al. Long-term risks and benefits of early-age gonadectomy in dogs. Journal of the American Veterinary Medical Association, v.224, n.3, p.380-387, 2004. Available from: <http://www.avma.org/avmacollections/spay_neuter/ javma_224_3_372.pdf>. Accessed: Jan. 25, 2011. 